\title{
A note on the use of immunofluorescent methods for the detection of Pseudomonas aeruginosa in bronchitic sputum
}

\author{
R. L. SANDS AND I. D. GREEN \\ From the Department of Bacteriology and Department of Medicine, University of Birmingham, \\ Birmingham B15 2TJ
}

SYNOPSIS By immunofluorescent microscopy of sputum from 67 cases of bronchitis Pseudomonas aeruginosa was detectable in 14 as compared with nine by cultural methods.

Recent studies have shown that immunological methods may be of value for the detection of infective agents in respiratory disease (Nicholls et al, 1975). Immunofluorescence has been employed for the diagnosis of Haemophilus in sputum (Sell et al, 1963).

Severe respiratory tract infections may be caused by $P$ s. aeruginosa during hospitalization and this organism may prove invasive. Thus its identification, in the early infective stages, is desirable (Perry and Sellors, 1963; Fraser and Paré, 1970).

\section{Material and Methods}

\section{HOMOLOGOUS ANTISERUM}

Ps. aeruginosa was obtained from a case of pneumonia in the Queen Elizabeth Hospital, Birmingham and found to be a non-typable polyagglutinating strain by the Cross-infection Laboratory, Colindale. Antiserum was raised in rabbits by the method of Yager et al (1960) using the inoculation schedule of Thomason and Cherry (1963). The agglutination titre of the antiserum against the homologous strain of Ps. aeruginosa was found by the Widal technique to be $1 / 250$, and it was subsequently shown by immunofluorescence to react with this strain and 14 newly isolated strains but failed to react with one. No cross-reactions were observed by either method with Haemophilus influenzae, Staphylococcus epidermidis, Proteus mirabilis, Klebsiella pneumoniae, Klebsiella aerogenes, group A streptococcus, $\alpha-$ haemolytic streptococcus or Neisseria catarrhalis.

\section{ANTISPECIES IMMUNOFLUORESCENT}

CONJUGATE

Commercial reagents having proved unsatisfactory, Received for publication 15 July 1975 immunofluorescent conjugate was prepared; sheep anti-rabbit immunoglobulin $G$ was obtained from the Department of Experimental Pathology, University of Birmingham, and conjugated to fluorescein isothiocyanate (FITC) isomer 1 using the method of Nairn (1969). Unconjugated fluorochrome and impurities present in the FITC were removed by passing $c 80 \mathrm{mg}$ of protein through a $2.5 \times 42 \mathrm{~cm}$ chromatography column containing Sigma G-25 Sephadex in a gel sample ratio of $6: 1(\mathrm{v} / \mathrm{v})$.

The purified conjugate was checked for the presence of unconjugated dye using polyacrylamide gel electrophoresis (PAGE) (Ornstein, 1964; Davis, 1964) and running the gels at $493 \mathrm{~nm}$ in a microdensitometer (Cartwright and Jeynes, 1972). The preparation was absorbed with ox liver homogenate supplied by the Department of Rheumatism Research, University of Birmingham by the technique of Nairn (1969).

The prepared conjugate was examined by PAGE, double gel diffusion (Ouchterlony, 1948), immunoelectrophoresis (Scheidegger, 1955), chessboard titration, incorporating normal rabbit serum against conjugate dilutions as a test for non-specific staining (Hale and Bergquist, 1971), and the fluores-

\begin{tabular}{|c|c|}
\hline$P A G E$ & No free dye detected \\
\hline $\begin{array}{l}\text { Double gel diffusion } \\
\text { Immunoelectrophoresis } \\
\text { Chessboard titration } \\
\text { Molar fluorescein to protein ratio }\end{array}$ & $\begin{array}{l}\text { Single arc of identity } \\
\text { Single arc of the IgG class } \\
\text { PEP } 1 / 64 \\
\text { PT } 1 / 200 \text { to } 1 / 500 \\
2: 3\end{array}$ \\
\hline \multicolumn{2}{|c|}{$\begin{array}{l}\text { PEP = plateau end-point } \\
\text { PT }=\text { plateau titre (Hale and Bergquist, 1971) }\end{array}$} \\
\hline $\begin{array}{l}\text { Table I Assessment of a fll } \\
\text { conjugate }\end{array}$ & tt antibody \\
\hline
\end{tabular}


cein to protein ratio (F:P) was calculated (Jobbágy and Király, 1966) (table I).

The conjugate was also tested for specificity against the previously listed bacteria, using the homologous antibacterial antiserum, prepared in this laboratory, for the indirect immunofluorescence test. Staining reactions were controlled for inhibition of fluorescent antibodies by pretreatment with unconjugated sheep anti-rabbit immunoglobulin $G$, and substitution of normal rabbit serum for the homologous antiserum.

\section{INDIRECT STAINING TECHNIQUE}

Heat-fixed bacterial smears were covered with homologous antiserum and incubated at room temperature for 1 hour in Petri dishes containing moist filter paper. Slides were washed in phosphate buffered saline (PBS) pH 7·2, 0·145M for 30 minutes and after the removal of excess moisture were incubated with homologous antispecies conjugate for 30 minutes. After the slides had been washed in PBS for 30 minutes the preparations were mounted in glycerol/PBS (9:1) and the coverslips were sealed with wax. Preparations were examined by dark-ground, blue fluorescence with the $\times 55$ oil immersion lens of a Gillett and Siebert 'Research Conference' microscope.

\section{BACTERIOLOGICAL METHODS}

Sputum samples were homogenized after pancreatin digestion and, for the purposes of comparison, were examined by Gram's stain and inoculated on horse blood agar and McConkey agar, incubated at $37^{\circ} \mathrm{C}$, and inspected after 24 and 48 hours. Colonies were picked, Gram-stained, and subcultured for further examination, in accordance with routine procedures.

\section{Results}

A specimen of sputum was taken from each of 67 subjects of various ages and both sexes, clinically diagnosed as bronchitic. Specimens were examined

\begin{tabular}{lc}
\hline & Pseudomonas aeruginosa \\
\hline Immunofluorescence located & 14 \\
Gram stain and culture & 9 \\
Location by both immunofluorescence, & 8 \\
Gram stain, and culture & \multicolumn{2}{c}{ Negative for immunofluorescence but } \\
positive for Gram stain and culture & 1 \\
Positive for immunofluorescence but & \multicolumn{2}{c}{ negative for Gram stain and culture } & 6 \\
\hline
\end{tabular}

Table II A comparison of immunofluorescence and routine bacteriology

Total number of patients investigated -67 by both cultural and immunofluorescence methods as soon as possible. The results are given in table II $\underline{\underline{T}}$ and show that more positive samples were obtained by immunofluorescence examination, while sub- $\stackrel{5}{9}$ stantiating, in all but one case, the results of culturalo methods. Control reactions were all negative.

\section{Discussion}

The results recorded show that immunofiuorescence provides a rapid and sensitive method of detecting. a potentially important pathogen in bronchitic $\vec{\omega}$ sputum, where rapid diagnosis provides the possi- $\stackrel{\omega}{\sigma}$ bility of early chemotherapy that might otherwise $\overline{0}$ be delayed.

Those cases in which a positive immunofluorescent $\stackrel{\sim}{\infty}$ diagnosis of Ps. aeruginosa was made, in the absence $\vec{N}$ of a positive culture, are explicable either by cultural $@$ failure or as false positives. The former might be caused by inadequate methods, transfer of anti- $\triangle$ biotics with the inocclum, low or non-viability of $\vec{\square}$ the bacteria. Improved selective cultural methods $\mathbb{D}$ should eliminate the discrepancy, but the work, as $\Phi$ presented, is intended to provide a comparison between this method and the cultural techniques $\stackrel{\mathbb{D}}{-}$ currently applied in a large number of hospital $\vec{\theta}$ laboratories.

We wish to thank Dr. K. A. Bisset for his help a advice.

\section{References}

Cartwright, N. J. and Jeynes, M. H. (1972). A densitometer 윽 attachment for gel electrophoretic measurements in the Unicam SP800 spectrophotometer. Lab. Pract., 21,

Davis, B. J. (1964). Disc electrophoresis. II. Method and application to human serum proteins. Ann. N.Y. Acad. Sci., 121, 404-427.

Fraser, R. G. and Paré, J. P. A. (1970). Diagnosis of Diseases of the Chest, vol. 1, p. 600. W. B. Saunders, Philadelphia, London and Toronto.

Hale, W. L. and Bergquist, R. (1971). Chessboard analyses with antinuclear antibodies. Ann. N.Y. Acad. Sci., 177,윽 354-360.

Jobbágy, A. and Király, K. (1966). Chemical characterisation $\frac{7}{O}$ of fluorescein isothiocyanate-protein conjugates. Biochem. Biophys. Acta, 124, 166-175.

Nairn, R. C. (1969). Fluorescent Protein Tracing, 3rd ed. Livingstone, Edinburgh and London.

Nicholls, A. C., Pease, P. E., and Green, I. D. (1975). N Agglutinin response to bacterial infection in acute exacer- $\omega$ bations of chronic bronchitis. J. clin. Path., 28, 279-283.

Ornstein, L. (1964). Disc-electrophoresis. I. Background ando theory. Ann. N.Y. Acad. Sci., 121, 321-349.

Ouchterlony, O. (1948). In vitro method for testing the toxin- $\bar{\perp}$ producing capacity of diphtheria bacteria. Acta path.microbiol. scand., 25, 186-191.

Perry, K. M. A. and Sellors, Sir T. H. (1963). Chest Diseases,, vol. 2. Butterworth, London. 
Scheidegger, J. J. (1955). Une micro-méthode de l'immunoélectrophorèse. Int. Arch. Allergy, 7, 103-110.

Sell, S. H. W., Saunders, R. S., and Cheatham, W. J. (1963). Hemophilus influenzae in respiratory infections. II. Specific serological antibodies identified by agglutination and immunofluorescent techniques. Amer. J. Dis. Child., 105, 470-474.

Thomason, B. M. and Cherry, W. B. (1963). Immuno- fluorescence techniques in the diagnosis of infections due to enteropathogenic Escherichia coli. Rev. lat-amer. Microbiol. Parasitol., 6, 63-76.

Yager, R. H., Spertzel, R. O., Jaeger, R. F., and Tigertt, W. D. (1960). Domestic fowl-source of high titer $P$. tularensis serum for the fluorescent antibody technic. Proc. Soc. exp. Biol. (N.Y.), 105, 651-654.

\section{Reports and Bulletins prepared by the Association of Clinical Biochemists}

The following reports and bulletins are published by the Association of Clinical Biochemists. They may be obtained from The Publishing Department, British Medical Journal (ACB Technical Bulletins), B.M.A. House, Tavistock Square, London WC1H 9JR. Overseas readers should remit by British Postal or Money Order.

SCIENTIFIC REPORTS (price $£ 1.00 / \$ 2.00$ each)

3 Automatic Dispensing Pipettes: an assessment of 35 commercial instruments September 1967 P. M. G. BROUGHTON, A. H. GOWENLOCK, G. M. WDDOWSON, and K. A. AHLQUIST

4 An Evaluation of five Commercial Flame Photometers suitable for the Simultaneous Determination of Sodium and Potassium March 1970 P. M. G. BROUGHTON and J. B. DAWSON

\section{SCIENTIFIC REVIEWS (price $£ 1 \cdot 00 / \$ 2.00$ each)}

1 The Assessment of Thyroid Function March 1971 F. V. FLYNN and J. R. HOBBS

2 Renal Function Tests Suitable for Clinical Practice January 1972 F. L. MITCHELL, N. VEALL, and R. W. E. WATTS

3 Biochemical Tests for the Assessment of Fetoplacental Function May 1975 C. E. WILDE and R. E. OAKEY

TECHNICAL BULLETINS (price $£ 1 \cdot 00 / \$ 2.00$ each)

9 Determination of Urea by AutoAnalyzer November 1966 RUTH M. HASLAM

11 Determination of Serum Albumin by AutoAnalyzer using Bromocresol Green October 1967 B. E. NORTHAM and G. M. WIDDOWSON

13 An Assessment of the Technicon Type II Sampler Unit March 1968 B. C. GRAY and G. K. MCGOWAN

14 Atomic Absorption Spectroscopy: an outline of its principles and a guide to the selection of instruments May 1968 J. B. DAWSON and P. M. G. BROUGHTON

15 A Guide to Automatic Pipettes (2nd edition) June 1968 P. M. G. BROUGHTON

16 A Guide to Automation in Clinical Chemistry May 1969 P. M. G. BROUGHTON

17 Flame Photometers: a comparative list of 17 instruments readily available in Britain August 1969 P. WILDING

19 Spectrophotometers: a comparative list of low-priced instruments readily available in Britain May 1970 C. E. WILDE and P. SEWELL
20 Quantities and Units in Clinical Biochemistry June 1970 P. M. G. BROUGHTON

21 Filter Fluorimeters: A comparative list of 18 instruments September 1970 H. BRAUNSBERG and s. $s$. BROWN

22 Bilirubin Standards and the Determination of Bilirubin by Manual and Technicon AutoAnalyzer Methods January 1971 BARBARA BILLING, RUTH HASLAM, and N. WALD

23 Interchangeable Cells for Spectrophotometers and Fluorimeters September 1971 S. S. BROWN and A. H. GOWENLOCK

24 Simple Tests to Detect Poisons March 1972 B. w. MEADE et al.

25 Blood Gas Analysers May 1972 k. DixoN

26 Kits for Enzyme Activity Determination September 1972 S. B. ROSALKI and D. TARLOW

27 Assessment of Pumps Suitable for Incorporation into Existing Continuous Flow Analytical Systems November 1972 A. FLECK et al.

28 Routine Clinical Measurements of Transferrin in Human Serum September 1973 K. DIXON

29 Control Materials for Clinical Biochemistry (5th edition) September 1973 J. F. STEVENS

30 Notes on the Quality of Performance of Serum Cholesterol Assays September 1973 s. s. BROWN

31 Determination of Uric Acid in Blood and in Urine July 1974 R. W. E. WATTS

32 A Survey of Amino Acid Analysers Readily Available in the United Kingdom September 1974 J. E. CARLYLE and P. PURKISS

33 Definitions of some Words and Terms used in Automated Analysis November 1974 A. FLECK, R. ROBINSON, S. S. BROWN, and J. R. HOBBS

34 Measurement of Albumin in the Sera of Patients January 1975 LINDA SLATER, P. M. CARTER, and J. R. HOBBS

35 Investigation of the Validity of Temperature Correction Factors for Serum Aspartate and Alanine Transaminases March 1975 S. B. ROSALKI et al. 